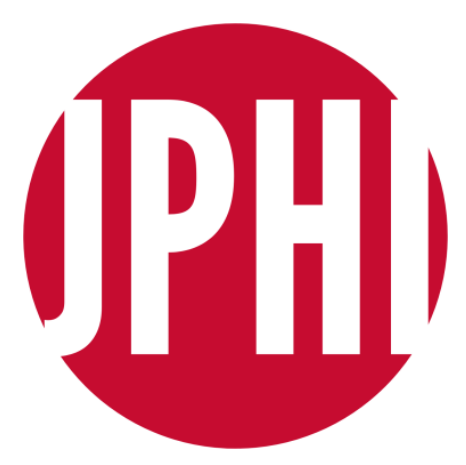

Jurnal Penegakan Hukum Indonesia (JPHI)

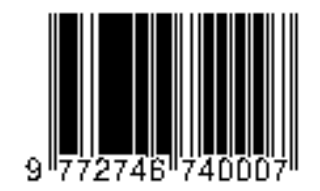

E-ISSN: 2746-7406

\section{PERLINDUNGAN HUKUM BAGI GURU YANG MEMBERIKAN SANKSI FISIK DALAM BATAS WAJAR TERHADAP PESERTA DIDIK}

\author{
Ahmad Gazali \\ Program Magister Hukum Litigasi, Fakultas Hukum \\ Universitas Gadjah Mada, Yogyakarta \\ Jl. Sosio Yustisia No. 1, Bulaksumur, Kab. Sleman, \\ Daerah Istimewa Yogyakarta (55281) \\ Email: ahmadelgazali189@gmail.com
}

$\begin{array}{ll}\text { Submitted } & : 19 / 09 / 2020 \\ \text { Revised } & : 06 / 10 / 2020 \\ \text { Accepted } & : 06 / 10 / 2020 \\ \text { Published } & : 28 / 01 / 2021\end{array}$

Editorial Office:

Jl. Brigjen H. Hasan Basri Komplek Polsek Banjarmasin Utara Jalur 3, No. 9 Kota Banjarmasin; Provinsi Kalimantan Selatan; Republik Indonesia (70125).

Email

jphi.scholarcenter@gmail.com

Principal Contact +62 82157709493

\section{(C) JPHI 2021}

Licensed under the CC 4.0.

Creative Commons

Attribution-ShareAlike 4.0

International License

\begin{abstract}
The purpose of this legal research is to find out how the legal arrangements for legal protection for teachers in providing physical sanctions within reasonable limits to students and to determine the impact of criminal cases that ensnare the teaching profession when carrying out their professional duties towards teachers in carrying out their professional duties. This research is a socio-legal research, by collecting primary and secondary data related to legal protection for teachers in providing physical sanctions within reasonable limits, then identified, analyzed and processed descriptively qualitatively. According to the results of this legal research show that: First, the legal protection for teachers in providing physical sanctions within reasonable limits to students in its arrangements has been very well proven by many laws and regulations and other legal rules that have been ratified, it's just that the application is felt still very lacking considering there are still many legal cases teachers whack teachers. Second, criminal cases that ensnare the teaching profession in carrying out their professional duties cause various impacts on teachers in carrying out their professional duties, including: fear and worry about being polished when giving disciplinary action to students, indifference towards wrongdoing or violation of norms committed students, as well as the criminalization and discrimination carried out by students and parents of students which reduces the professionalism of the teacher so that the teacher's performance is not optimal in the role of educating the administrators of the nation so that it is not achieved from national education goals.
\end{abstract}

Keywords: legal protection; punishment; teacher.

\section{Abstrak}

Tujuan dari penelitian hukum ini adalah untuk mengetahui bagaimana pengaturan hukum terhadap perlindungan hukum bagi guru dalam 
memberikan sanksi fisik dalam batas wajar terhadap peserta didik dan untuk mengetahui dampak dari kasus-kasus pidana yang menjerat profesi guru ketika melaksanakan tugas profesinya terhadap para guru dalam menjalankan tugas profesinya. Penelitian ini merupakan penelitian hukum yuridis sosiologis, dengan mengumpulkan data primer dan data sekunder terkait perlindungan hukum bagi guru dalam memberikan sanksi fisik dalam batas wajar, selanjutnya diidentifikasi, dianalisa dan diolah secara deskriptif kualitatif. Menurut hasil penelitian hukum ini menunjukkan bahwa: Pertama, menegenai perlindungan hukum bagi guru dalam memberikan sanksi fisik dalam batas wajar terhadap peserta didik dalam pengaturannya sudah sangat baik terbukti dari banyaknya peraturan perundang-undangan serta aturan hukum lain yang telah disahkan, hanya saja dalam penerapannya dirasa masih sangat kurang mengingat masih banyak guru kasus-kasus hukum yang mendera guru. Kedua, kasus-kasus pidana yang menjerat profesi guru dalam melaksanakan tugas profesinya menimbulkan berbagai dampak terhadap guru dalam menjalankan tugas profesinya, diantaranya: rasa takut dan kekhawatiran akan dipolisikan manakala memberi tindakan kedisiplinan kepada peserta didik, sikap acuh terhadap perbuatan salah atau pelanggaran norma yang dilakukan peserta didik, serta kriminalisasi dan deskriminasi yang dilakukan oleh peserta didik maupun orang tua peserta didik yang mana menurunkan keprofesionalan dari guru sehingga kurang optimalnya kinerja guru dalam peran mendidik para penurus bangsa sehingga tidak tercapai dari tujuan pendidikan nasional.

Kata Kunci: perlindungan hukum; sanksi hukuman; guru.

\section{PENDAHULUAN}

Dunia pendidikan sejatinya adalah suatu sarana untuk mencapai tujuan nasional serta sebagai sarana untuk membentuk karakter suatu bangsa. Di dunia pendidikan terdapat dua elemen penting yang tak dapat di pisahkan yaitu Guru dan Murid. Guru adalah sebuah profesi yang sangat mulia di mata masyarakat Indonesia, guru berperan sebagai pendidik, pengajar, pembimbing, pelatih dan pengarah muridnya agar menjadi pribadi yang berkarakter, berbudi pekerti luhur, sehingga mampu menjadi penerus bangsa ini agar menjadi bangsa yang besar. Tidak hanya itu, tingkah laku guru didalam kehidupan bermasyarakat pun merupakan suatu teladan bagi masyarakat Indonesia tak heran dengan tanggung jawab sebesar itu profesi seorang guru merupakan profesi yang memiliki martabat yang tinggi di mata masyarakat.

Seorang guru mempunyai kepribadian yang khas, disatu sisi guru harus ramah, sabar, menunjukkan pengertian, memberikan kepercayaan dan menciptakan suasana aman. Akan tetapi di lain sisi, guru harus memberikan tugas, mendorong 
siswa untuk mencapai tujuan, menegur, menilai, dan mengadakan koreksi. Dengan demikian, kepribadian seorang guru seolah-olah terbagi menjadi 2 bagian. Di satu sisi bersifat empati, di sisi lain bersifat kritis. Di satu sisi menerima, di lain sisi menolak. Maka seorang guru yang tidak bisa memerankan pribadinya sebagai guru, ia akan berpihak kepada salah satu pribadi saja. Dan berdasarkan hal-hal tersebut, seorang guru harus bias memilah serta memilih kapan saatnya berempati kepada siswa, kapan saatnya kritis, kapan saatnya menerima dan kapan saatnya menolak. Dengan perkatan lain,seorang guru harus mampu berperan ganda. Peran ganda ini dapat di wujudkan secara berlainan sesuai dengan situasi dan kondisi yang dihadapi.

Dunia pendidikan mengenal adanya pemberian penghargaan (reward) dan hukuman (punishment), sebagai salah satu alat pendidikan pemberian hukuman(punishment) kepada siswa yang melanggar bertujuan untuk mendidik siswa tersebut. Hukuman yang diberikan bisa dalam bentuk teguran lisan ataupun tertulis, bisa juga dalam bentuk hukuman lain yang bersifat mendidik, memberikan efek jera untuk tidak mengulanginya. Tujuannya adalah agar siswa tahu akan norma dan aturan yang berlaku.

Guru dalam menjalankan tugas profesinya yang mana telah tertuang dalam peraturan perundangan-undangan barang kali tentu sudah diiringi dengan perlindungan. Perlindungan merupakan sesuatu hal yang menjadi aspek terpenting di dalam kehidupan manusia dalam menjalani aktivitasnya sehari-hari. Dikatakan sebagai aspek terpenting karena perlindungan memberi suatu jaminan untuk keselamatan, kesehatan, dan keamanan dalam hidup manusia. Republik Indonesia yang merupakan negara yang berlandaskan hukum masalah perlindungan diatur dalam Pembukaan Undang-Undang Dasar Negara Republik Indonesia (UUD NRI) Tahun 1945 alinea ke-4 yang berbunyi "melindungi segenap bangsa Indonesia dan seluruh tumpah darah Indonesia, memajukan kesejahteraan umum, mencerdaskan kehidupan berbangsa dan ikut melaksanakan ketertibandunia". Oleh karena itu tujuan tersebut harus diwujudkan demi terwujudkan tujuan negara yang sesungguhnya, termasuk pula dalam hal ini perlindungan hukum.

Menurut C.S.T. Kansil Perlindungan Hukum adalah berbagai upaya hukum yang harus diberikan oleh aparat penegak hukum untuk memberikan rasa aman, baik secara pikiran maupun fisik dari gangguan dan berbagai ancaman dari pihak 
manapun. ${ }^{1}$ Namun dewasa ini martabat yang tinggi itu tercoreng oleh beberapa kasus pemidanaan terhadap guru yang membuat hati kita miris manankala mengetahui bahwa guru yang dipidina karena justru pada saat mereka sedang melakukan tugas profesinya yang mulia yaitu pada saat sedang mendidik muridnya agar menjadi seorang yang disiplin.

Maraknya berbagai kasus yang menimpa guru dalam menjalankan tugas profesinya merupakan salah satu bukti bahwa Perlindungan hukum terhadap profesi guru belum berjalan dengan benar atau sebagaimana seharusnya. Guru sebagai profesi yang mulia/terhormat (officium Nobile), sebagaimana profesi-profesi lainnya, rupanya belum dipahami benar oleh masyarakat pada umumnya dan khususnya aparat penegak hukum yang merupakan kepanjangan tangan dari pemerintah. Meningkatnya berbagai permasalahan yang menimpa guru telah menyudutkan profesi terhormat dari guru. Tindakan-tindakan guru kepada peserta didik, dalam kerangka mendidik terkadang diterima "salah" oleh orang tua peserta didik dan merupakan perbuatan yang tidak termaafkan sehingga harus diselesaikan dengan tindak kekerasan bahkan sampai ke meja hijau. Kondisi ini kemudian dimanfaatkan oleh sekelompok "profesional" dari bidang lain guna mengambil keuntungan pribadi dengan melakukan "blow up" besar-besaran melalui berbagai media.

\section{RUMUSAN MASALAH}

Berdasarkan latar belakang diatas penulis akan mengakaji beberapa objek permasalahan yang penulis anggap sebagai permasalahan yang cukup krusial yang penulis rumumuskan sebagai berikut:

1. Bagaimana pengaturan hukum terhadap perlindungan hukum bagi guru dalam memberikan sanksi fisik dalam batas wajar terhadap peserta didik?

2. Bagaimana dampak dari kasus-kasus pidana yang menjerat profesi guru dalam melaksanakan tugas profesinya terhadap para guru dalam menjalankan tugas profesinya?

\footnotetext{
${ }^{1}$ C.S.T. Kansil, Pengantar Ilmu Hukum dan Tata Hukum Indonesia, (Jakarta: Balai Pustaka, 1989), hlm
} 102. 


\section{METODE PENELITIAN}

Penelitian yang dilakukan dalam konteks ilmu hukum, maka kajian itu adalah tentang permasalahan pada penerapan hukum, proses hukum, peristiwa hukum, dan ketentuan peraturan hukum itu sendiri baik secara substansi maupun prosedural. ${ }^{2}$ Dalam penelitian ini penulis menggunakan metode pendekatan yuridis empiris atau yuridis sosiologis. Dalam pendekatan yuridis sosiologis, hukum sebagai law in action, dideskripsikan sebagai gejala sosial yang empiris. Dengan demikian hukum tidak sekedar diberikan arti sebagai jalinan nilai-nilai, keputusan pejabat, jalinan kaidah dan norma, hukum positif tertulis, tetapi juga dapat diberikan makna sebagai sistem ajaran tentang kenyataan, perilaku yang teratur dan ajek, atau hukum dalam arti petugas. Dengan pendekatan ini maka diharapkan apakah perlindungan hukum bagi guru dalam memberikan sanksi fisik dalam batas wajar, sudah ada kesesuaian antara peraturan yang berlaku dengan kenyataan sosialnya atau dengan kata lain, kesesuaian antara law in books dengan law in action atau kesesuaian antara das sollen dengan das sein.

Selain itu penulis juga menggunakan metode deskriptif analitis yaitu melakukan deskripsi terhadap hasil penelitian dengan data yang selengkap dan sedetail mungkin. Deskripsi yang dimaksud adalah terhadap data primer dan juga data sekunder yang berhubungan dengan perlindungan hukum bagi guru dalam memberikan sanksi fisik dalam batas wajar. Selanjutnya dilakukan analisis terhadap hasil penelitian dengan menggunakan peraturan perundang-undangan dan teori yang relevan.

Untuk mendapat data yang akurat dan faktual, maka diperlukan data primer dan data sekunder yang penulis peroleh dari:

a. Data primer

Data primer adalah data yang diperoleh secara langsung dari objeknya. ${ }^{3}$ Data primer diperoleh atau dikumpulkan dengan melakukan studi lapangan ( field research) dengan cara wawancara, dengan menggunakan teknik purposive sampling yang artinya pengambilan Narasumber tidak dipilih secara acak (random sampling) tetapi sudah dipilah oleh penulis untuk tujuan dan

\footnotetext{
${ }^{2}$ Yati Nurhayati, Ifrani, \& M. Yasir Said, (2021), Metodologi Normatif dan Empiris Dalam Perspektif Ilmu Hukum, Jurnal Penegakan Hukum Indonesia, Vol. 2, No.1, Tahun 2021, hlm.1-20

${ }^{3}$ J. Supranto, Metode Penelitian Hukum dan Statistik, (Jakarta: PT Rineka Cipta, 2003), hlm. 2
} 
pertimbangan tertentu. ${ }^{4}$ Wawancara adalah proses tanya jawab dalam penelitian yang berlangsung secara lisan dimana dua orang atau lebih bertatap muka mendengarkan secara langsung informasi-informasi atau keteranganketerangan. ${ }^{5}$ Wawancara ini dilakukan dengan metode depth Interview (wawancara langsung secara mendalam). Data Primer ini akan diambil dari wawancara kepada Aparat Penegak Hukum dan Akademisi atau para pakar terkait permasalahan yang diteliti. Adapun yang menjadi narasumber dalam penelitian ini yaitu:

1) PS. Kanit IDIK IV Unit Perlindungan Perempuan dan Anak (PPA) Polres Banjar yaitu Bapak Lukman Hakim.

2) Ketua Persatuan Guru Republik Indonesia (PGRI) kabupaten Banjar yaitu Bapak Drs. Muhammad Arsyad, M.Pd.

3) Pakar Hukum Pidana atau Dosen Hukum Pidana Universitas Islam Kalimantan Muhammad Arsyad Al-Banjari yaitu Bapak Akhmad Munawar, S.H., M.H.

b. Data sekunder

Data sekunder adalah data yang diperoleh melalui bahan kepustakaan. ${ }^{6}$ Pengumpulan data ini dilakukan dengan studi atau penelitian kepustakaan (library research) yaitu dengan mempelajari peraturan-peraturan, buku-buku yang berkaitan dengan penelitian. Data sekunder yang dikumpulkan terdiri dari data sekunder dari bahan hukum primer dan bahan hukum sekunder serta bahan hukum tersier.

1) Data sekunder dari bahan hukum primer

Menurut Soerjono Soekanto bahan hukum primer yaitu bahan-bahan hukum yang mengikat dan terdiri dari norma atau kaidah dasar yaitu Pembukaan Undang-Undang Dasar 1945, peraturan dasar, peraturan perundang-undangan, bahan hukum yang tidak dikodifikasikan misalnya hukum adat, yurisprudensi, traktat dan KUHP. ${ }^{7}$

Data sekunder dari bahan hukum primer dalam penelitian ini berupa:

a) Undang-Undang Dasar Negara Republik Indonesia Tahun 1945

\footnotetext{
${ }^{4}$ Sugiyono, Metode Penelitian Kunatitatif Kualitatif dan R\&D, (Bandung: Alfabeta, 2010), hlm. 85

${ }^{5}$ Cholid Narbuko dan Abu Achmadi, Metodologi Penelitian, (Jakarta: Bumi Aksara, 2001), hlm. 81.

${ }^{6}$ Ronny Hanitijo Soemitro, Metode Penelitian Hukum dan Yurimetri. (Jakarta: Ghalia, 1994), hlm. 11.

${ }^{7}$ Soerjono Soekanto, Pengantar Penelitian Hukum. (Jakarta: UI Press, 1981), hlm.151-152.
} 
b) Undang-Undang Nomor 1 Tahun 1946 tentang Peraturan Hukum Pidana atau selanjutnya disebut Kitab Undang-Undang Hukum Pidana (KUHP).

c) Undang-Undang Republik Indonesia Nomor 8 Tahun 1981 tentang Kitab Undang-Undang Hukum Acara Pidana.

d) Undang-Undang Republik Indonesia Nomor 20 Tahun 2003 Tentang Sistem Pendidikan Nasional.

e) Undang-Undang Republik Indonesia Nomor 14 Tahun 2005 Tentang Guru dan Dosen.

f) Undang-Undang Republik Indonesia Nomor 23 Tahun 2002 Tentang Perlindungan Anak Jo.Undang-Undang Republik Indonesia Nomor 35 Tahun 2014 Tentang Perubahan Atas Undang-Undang Republik Indonesia Nomor 23 Tahun 2002 Tentang Perlindungan Anak.

g) Peraturan Pemerintah Republik Indonesia Nomor 74 Tahun 2008 Tentang Guru. Jo. Peraturan Pemerintah Republik Indonesia Nomor 19 Tahun 2017 Tentang Perubahan Atas Peraturan Pemerintah Republik Indonesia Nomor 74 Tahun 2008 Tentang Guru.

h) Yurisprudensi atau Putusan Mahkamah Agung Republik Indonesia No. $1554 \mathrm{~K} / \mathrm{PID} / 2013$

2) Data sekunder dari bahan hukum sekunder berupa: buku-buku teks, jurnal hasil penelitian yang berkaitan dengan permasalahan yang diteliti.Dokumen atau arsip resmi atau arsip yang berkaitan dengan perlindungan hukum bagi guru dalam memberikan sanksi fisik dalam batas wajar.

3) Data sekunder dari bahan hukum tersier berupa kamus bahasa Indonesia atau kamus hukum.

\section{PEMBAHASAN}

\section{Pengaturan Hukum Terhadap Perlindungan Hukum Bagi Guru Dalam Memberikan Sanksi Fisik Dalam Batas Wajar Terhadap Peserta Didik}

Adapun pengertian dan tugas dari seorang guru telah di atur didalam Undang-Undang Nomor 14 tahun 2005 tentang Guru dan Dosen, dalam Pasal 1 angka 1 dinyatakan bahwa: "Guru adalah pendidik professional dengan tugas 
utama mendidik, mengajar, membimbing, mengarahkan, melatih, menilai, dan mengevaluasi, peserta didik dalam pendidikan anak usia dini, jalur pendidikan formal,pendidikan dasar,dan pendidikan menengah." Dari pengertian tersebut, Guru tidak hanya sebagai Pengajar yang hanya menyampaikan materi pelajaran kepada siswa. Guru juga dituntut menjalankan peran-perannya sebagai guru dalam usahanya mencapai tujuan pembelajaran dan mengembangkan potensi siswa. Diantaranya yai tu sebagai seorang Pendidik yang peran-peran yang berkaitan dengan tugas-tugas memberi bantuan dan dorongan (supporter), tugas-tugas pengawasan dan pembinaan (supervisior) serta tugas-tugas yang mendisiplinkan anak agar menjadi patuh terhadap aturan-aturan sekolah dan norma hidup dalam keluarga dan masyarakat.

Tugas-tugas ini berkaitan dengan pertumbuhan dan perkembangan anak untuk memperoleh pengalaman-pengalaman lebih lanjut penggunaan kesehatan jasmani, bebas dari orang tua, dan orang dewasa yang lain, moralitas, tanggung jawab kemasyarakatan, pengetahuan, dan keterampilan dasar, persiapan untuk perkawinan dan hidup berkeluarga, pemilihan jabatan, dan hal-hal yang bersifat personal dan spiritual. Oleh karena itu tugas guru dapat disebut pendidik dan pemeliharaan anak. Guru sebagai penanggung jawab pendisiplin anak harus mengontrol setiap anak, agar tingkah laku anak tidak menyimpang dari normanorma yang ada.

Dari banyaknya tanggung jawab dan kewajiban yang harus diemban profesi guru tentu haruslah diberi apresiasi atau pemberian bermacam hak dan perlindungan, guna guru dapat optimal dalam melaksanakan kewajibannya yang mana merupakan amanat undang-undang. Berbagai hak serta perlindungan telah disematkan bagi profesi guru yang telah diatur di berbagai macam peraturan perundang-undangan diantaranya:

1. Undang-Undang Republik Indonesia Nomor 20 tahun 2003 tentang Sistem Pendidikan Nasional

Didalam undang-undang ini tidak mengatur secara eksplisit mengenai masalah perlindungan bagi Pendidik dan Tenaga Kependidikan secara umum dan guru secara khususnya. Didalam undang-undang ini mengatur tentang apa yang 
menjadi hak dan kewajiban oleh seorang Pendidik dan tenaga kependidikan. Hal ini terdapat didalam pasal 40 , yang menyebutkan:

(1) Pendidik dan tenaga kependidikan berhak memperoleh :

a. penghasilan dan jaminan kesejahteraan sosial yang pantas dan memadai;

b. penghargaan sesuai dengan tugas dan prestasi kerja;

c. pembinaan karier sesuai dengan tuntutan pengembangan kualitas;

d. perlindungan hukum dalam melaksanakan tugas dan hak atas hasil kekayaan intelektual; dan

e. kesempatan untuk menggunakan sarana, prasarana, dan fasilitas pendidikan untuk menunjang kelancaran pelaksanaan tugas.

Berdasarkan uraian pasal 40 diatas, masalah perlindungan hukum bagi guru secara khusus hanya disebutkan didalam Ayat 1 huruf $d$, dan hanya secara ringkas disebutkan yaitu perlindungan hukum dalam melaksanakan tugas. Perlindungan hukum disini meliputi perlindungan untuk rasa aman, perlindungan terhadap pemutusan hubungan kerja, dan perlindungan keselamatan dan kesehatan kerja. Dalam melaksanakan tugas yang dimaksud meliputi ketika guru melaksanakan tugas keprofesionalannya yaitu didalam merencanakan dan melaksanakan proses pembelajaran,baik didalam satuan pendidikan formal ataupun non formal.

2. Undang-Undang Republik Indonesia Nomor 14 tahun 2005 tentang Guru dan Dosen

Pada undang-undang ini masalah perlindungan guru telah diatur secara eksplisit dan khusus pada Pasal 39 Bagian Ketujuh yang mengemukakan sebagai berikut:

(1) Pemerintah, pemerintah daerah, masyarakat, organisasi profesi, dan/atau satuan pendidikan wajib memberikan perlindungan terhadap guru dalam pelaksanaan tugas.

(2) Perlindungan sebagaimana dimaksud pada ayat (1) meliputi perlindungan hukum, perlindungan profesi, serta perlindungan keselamatan dan kesehatan kerja.

(3) Perlindungan hukum sebagaimana dimaksud pada ayat (2) mencakup perlindungan hukum terhadap tindak kekerasan, ancaman, perlakuan diskriminatif, intimidasi, atau perlakuan tidak 
adil dari pihak peserta didik, orang tua peserta didik, masyarakat, birokrasi, atau pihak lain.

(4) Perlindungan profesi sebagaimana dimaksud pada ayat (2) mencakup perlindungan terhadap pemutusan hubungan kerja yang tidak sesuai dengan peraturan perundangundangan, pemberian imbalan yang tidak wajar, pembatasan dalam menyampaikan pandangan, pelecehan terhadap profesi, dan pembatasan/pelarangan lain yang dapat menghambat guru dalam melaksanakan tugas.

(5) Perlindungan keselamatan dan kesehatan kerja sebagaimana dimaksud pada ayat (2) mencakup perlindungan terhadap risiko gangguan keamanan kerja, kecelakaan kerja, kebakaran pada waktu kerja, bencana alam, kesehatan lingkungan kerja, dan/atau risiko lain.

Frasa perlindungan hukum yang dimaksudkan disini mencakup semua dimensi yang terkait dengan upaya mewujudkan kepastian hukum, kesehatan, keamanan, dan kenyamanan bagi guru dalam menjalankan tugas-tugas profesionalnya. Sehingga semua guru harus dilindungi secara hukum dari segala anomali atau tindakan semena-mena dari yang mungkin atau berpotensi menimpanya dari pihakpihak yang tidak bertanggungjawab. Perlindungan hukum yang dimaksud meliputi perlindungan yang muncul akibat tindakan dari peserta didik, masyarakat,birokrasi atau pihak lain, berupa : 1) Tindak kekerasan; 2) Ancaman, baik secara fisik ataupun psikologis; 3) Perlakuan diskriminatif; 4) Intimidasi; dan 5) Perlakuan tidak adil. Pasal 39 ini pada dasarnya merupakan jaminan dan perlindungan secara yuridis bagi guru didalam melaksanakan tugas keprofesionalannya.

Lebih lanjut pengaturan hukum terhadap perlindungan hukum bagi dalam memberikan sanksi fisik pada saat menjalankan tugas profesinya atau pada saat proses belajar mengajar diatur berbagai macam aturan hukum yaitu:

1. Peraturan Pemerintah Republik Indonesia Nomor 74 Tahun 2008 tentang Guru Jo. Peraturan Pemerintah Republik Indonesia Nomor 19 Tahun 2017 tentang Perubahan Atas Peraturan Pemerintah Republik Indonesia Nomor 74 Tahun 2008 tentang Guru.

Dalam Pasal 39 ayat (1) menyatakan bahwa:

"Guru memiliki kebebasan memberikan sanksi kepada peserta didiknya yang melanggar norma agama, norma kesusilaan, norma kesopanan, peraturan tertulis maupun tidak tertulis yang di tetapkan guru, peraturan tingkat satuan pendidikan, dan peraturan 
perundang-undangan dalam proses pembelajaran yang berada dibawah kewenangannya."

Dalam Pasal 39 ayat (2) dijelaskan mengenai jenis sanksi, yakni:

"Sanksi sebagaimana dimaksud ayat (1) dapat berupa teguran dan/atau peringatan, baik lisan maupun tulisan, serta hukuman yang bersifat mendidik sesuai dengan kaedah pendidikan, kode etik guru, dan perturan perundang-undangan."

Dalam Peraturan ini juga memberikan perlindungan terhadap guru dalam menegakan disiplin terhadap muridnya, tepatnya dalan Pasal 40 menyebutkan:

"Guru berhak mendapatkan perlindungan dalam melaksanakan tugas dalam bentuk rasa aman dan jaminan keselamatan dari pemerintah, pemerintah daerah, satuan pendidikan, organisasi profesi guru, dan/atau masyarakat sesuai dengan kewenangan masing-masing"

Dalam Pasal 41 PP No. 74 tahun 2008 juga menyebutkan bahwa:

"Guru berhak mendapatkan perlindungan dari tindak kekerasan, ancaman, perlakuan diskriminatif, intimidasi, atau perlakuan tidak adil dari pihak peserta didik, orang tua peserta didik, masyarakat, birokrasi, atau pihak lain."

2. Yurisprudensi Mahkamah Agung (MA) No. 1554 K/PID/2013

Pemberian sanksi fisik oleh guru terhadap murid juga dibenarkan berdasarkan yurisprudensi Mahkamah Agung (MA) No. 1554 K/PID/2013 menyatakan bahwa guru tidak bisa dipidana saat menjalankan profesinya dan melakukan tindakan pendisiplinan terhadap siswa, dengan pertimbangan bahwa apa yang yang dilakukan guru adalah sudah menjadi tugasnya, dan bukan merupakan suatu tindak pidana, dan guru tidak dapat dijatuhi pidana atas perbuatan/tindakannya tersebut, karena bertujuan untuk mendidik agar menjadi murid yang baik dan disiplin.

3. MoU POLRI dengan PGRI No. B/53/XII/2012 dan No. 1003/UM/PB/XX/2012

MoU antara POLRI dan PGRI ini merupakan suatu pedoman kerja antara POLRI dengan PGRI yaitu tentang mekanisme penanganan perkara dan pengamanan terhadap profesi guru. Yang menjadi latar belakang lahirnya MoU ini dikarenakan perlindungan hukum dan keamanan bagi guru dalam menjalankan profesinya sampai sekarang belum ada rumusan atau pedoman 
kerja yang komprehensif sehingga terjadi kesimpangsiuran dan kesalahpahaman antara Guru dan Polri. Sehubungan dengan hal itu maka perlu dirumuskan pedoman kerja yang memungkinkan terwujudnya perlindungan hukum, dan keamanan bagi profesi guru.

Didalam MoU ini menjelaskan pengaturan tentang penggolongan perbuatan guru yang dapat mengakibatkan timbulnya perbuatan tindak pidana pada saat melaksanakan tugas keprofesiannya. Hal ini diatur pada Bab II tentang penggolongan dan Kedudukan. Penggolongan perbuatan guru ini adalah :

a. Perbuatan guru yang tidak disengaja

Perbuatan guru yang tidak disengaja yang dapat menimbulkan perbuatan tindak pidana menurut kesalahpahaman atau salah pengertian dari peserta didik atau orang tua / wali pada saat melaksanakan tugas keprofesionalan antara lain adalah

1) Guru yang tidak menanyakan kesiapan kesehatan, kondisi fisik, dan psikis kepada peserta didik sebelum memulai proses pembelajaran, tidak merupakan tanggung jawab guru karena kesiapan proses belajar adalah tanggungjawab orang tua/wali dan peserta didik.

2) Guru menyentuh bagian badan peserta didik yang dianggap pelecehan seksual pada saat serangkaian kegiatan proses pembelajaran.

3) Guru yang dalam melakukan serangkaian kegiatan proses pembelajaran, tanpa disengaja, alat/bahan praktik mengajarnya mengenai bagian tubuh peserta didik yang mengakibatkan cedera/luka.

4) Guru yang tidak sengaja memberi penjelasan yang mengandung nilai SARA dan politik tidak dianggap bersalah jika kemudian dilakukan perbaikan atau pembetulan dari materi/referensi/bahan ajar yang disampaikan dalam proses pembelajaran.

5) Perbuatan lain yang tidak disengaja oleh guru yag dapat menimbulkan perbuatan pidana menurut kesalahpahaman atau salah pengertian dari peserta didik dan atau orang tua/wali. 
b. Perbuatan guru yang rawan menimbulkan tindak pidana

Perbuatan guru yang disengaja yang rawan mengakibatkan timbulnya tindak pidana pada saat melaksanakan tugas keprofesian yang apabila disikapi sepihak dan tidak bijaksana oleh peserta didik dan atau orang tua/wali/masyarakat. Adapun perbuatan guru yang termasuk pada golongan yang kedua ini adalah:

1) Guru yang memberikan penguatan (enforcement) dengan menepuk pundak, menepuk punggung, berjabat tangan, dan memegang kepala peserta didik sepanjang tidak bertentangan dengan nilai budaya bangsa pada saat serangkaian kegiatan proses pembelajaran.

2) Guru yang memberi sanksi kepada peserta didik berupa fisik maupun psikis sepanjang bertujuan untuk mendidik dan tidak bermaksud mencederai pada saat serangkaian kegiatan proses pembelajaran.

3) Guru yang melakukan tindakan menegakkan tata tertib sekolah yang sudah disepakati oleh orang tua/wali, peserta didik, dan pihak sekolah.

4) Guru dalam menjelaskan materi pembelajaran yang mengandung unsur-unsur kesusilaan selama tidak menyimpang dari materi pembelajaran.

5) Guru berhak membawa peralatan apapun selama tidak menyimpang dari materi pembelajaran yang diajarkan.

6) Guru yang menjelaskan materi pembelajaran yang mengandung unsur-unsur kesusilaan selama tidak menyimpang dari materi pembelajaran.

7) Guru yang mengadakan les/tambahan pelajaran disekolah maupun di luar sekolah yang dapat menimbulkan tindak pidana.

8) Guru yang membedakan memberikan hukuman pada muridnya.

9) Perbuatan lain yang disengaja oleh guru yang rawan menimbulkan perbuatan tindak pidana apabila disikapi sepihak oleh peserta didik dan atau orang tua/wali. 
c. Perbuatan Guru yang disengaja

Perbuatan guru yang disengaja yang mengakibatkan timbulnya perbuatan tindak pidana pada saat melaksanakan tugas keprofesian antara lain adalah:

1) Guru yang dengan sengaja melakukan tindak pidana berupa penganiayaan kepada peserta didik pada saat dilaksanakan serangkaian proses pembelajaran.

2) Guru yang dengan sengaja melakukan perbuatan tindak pidana berupa pelecehan seksual kepada peserta didik pada saat dilaksanakan serangkaian kegiatan proses pembelajaran.

3) Guru yang dengan sengaja melakukan perbuatan tindak pidana berupa perbuatan yang tidak menyenangkan keada peserta didik pada saat dilaksanakan serangkaian kegiatan pembelajaran.

4) Guru yang dengan sengaja melakukan perbuatan tindak pidana berupa pencurian terhadap barang milik sekolah dan barang milik peserta didik.

5) Guru yang dengan sengaja melakukan perbuatan tindak pidana berupa pengrusakan terhadap barang milik sekolah dan barang milik peserta didik.

6) Guru dengan sengaja menyuruh peserta didik untuk melakukan perbuatan yang tergolong tindak pidana.

7) Guru yang dengan sengaja melakukan pungutan uang atau barang kepada peserta didik di luar ketentuan sekolah.

8) Perbuatan lain yang dengan sengaja dapat menimbulkan perbuatan tindak pidana pada saat kegiatan proses pembelajaran.

d. Perbuatan guru dengan niat melakukan tindak pidana

Perbuatan guru yang disengaja yang dapat mengakibatkan timbulnya perbuatan tindak pidana pada saat melaksanakan pekerjaan keprofesian antara lain adalah:

1) Guru melakukan dan atau jual beli narkoba.

2) Guru melakukan perbuatan perjudian dan atau sebagai bandar perjudian. 
3) Guru bertindak sebagai mucikari

4) Perbuatan tindak pidana yang lainnya sebagaimana yang diatur dalam perundang-undangan.

e. Perbuatan guru tidak disengaja yang dapat menimbulkan tindak pidana

Guru yang tindak sengaja melakukan perbuatan tindak pidana yang tidak berkaitan dengan profesinya, misalnya guru yang karena kelalaiannya berkaitan dengan kecelakaan lalu lintas.

Berdasarkan uraian pengaturan mengenai penggolongan perbuatan guru diatas, dapat dilihat penjelasan terhadap perbuatan-perbuatan guru yang dapat menimbulkan tindak pidana dalam kegiatan belajar mengajar. Penggolongan perbuatan tersebut seharusnya dapat menjadi dasar pertimbangan bagi hakim atau kepolisian terhadap guru yang diindikasikan melakukan tindak pidana terhadap guru. Penggolongan perbuatan guru ini dapat menjadi dasar perlindungan bagi guru dalam proses belajar mengajar apabila guru memberikan suatu hukuman yang bertujuan untuk mendidik, menegakkan displin, untuk kebaikan anak didik (murid) dan tidak bermaksud untuk mencederai.

Pada MoU ini juga dijelaskan tentang kedudukan guru dalam proses hukum, dimana disebutkan :

a. penyidikan tindak pidana yang dilakukan terhadap guru tetap berdasar kepada azas praduga tak bersalah dan guru tidak mempunyai hak istimewa, namun demikian:

1) Dalam rangka upaya paksa terhadap guru, tidak dilakukan dalam proses pembelajaran kecuali patut diduga terdapat barang bukti yang ada padanya terhadap tindak pidana tertentu (misalnya: narkoba) dan atau tindak pidana yang dapat membahayakan jiwanya.

2) Upaya paksa yang dilakukan oleh POLRI memperhatikan etika, situasi, dan sosial hukum dalam rangka memberikan perlindungan profesi dan keamanan guru.

b. Perbuatan tindak pidana yang tidak disengaja dan perbuatan yang rawan timbulnya tindak pidana yang berkaitan dengan profesi, proses penyelesaian hukumnya diutamakan dengan perdamaian, dalam rangka 
menjaga kewibawaan guru dengan tidak menyalahi dan tetap berdasarkan peraturan perundang-undangan.

Berdasarkan uraian diatas, ketika guru dalam proses hukum, tetap dengan berdasarkan pada azas praduga tak bersalah, dan dalam menggunakan upaya paksa dilakukan tidak pada saat proses kegiatan belajar atau proses pembelajaran. Dan diutamakan dengan perdamaian dalam rangka menjaga status dan kewibawaan guru.

MoU ini juga mengatur tentang pedoman pelaksanaan perlindungan hukum dan keamanan, sebagaimana diatur dalam Bab IV, yaitu sebagai berikut:

a. Perlindungan hukum dalam upaya paksa

1) Penyelidikan

PGRI berikut komponennya yang berkepentingan membantu penyidik untuk dapat segera memperoleh informasi untuk menentukan saksi dan tersangka serta barang bukti guna membuat terang suatu perkara tindak pidana dimana penyelidikan yang dilakukan oleh Polri tersebut mempertimbangkan hal-hal sebagai berikut:

a) Waktu pada saat kegiatan proses pembelajaran

b) Situasi dan tempat kegiatan proses pembelajaran

c) Menjaga harmonisasi antara guru dengan peserta didik.

2) Pemanggilan

Polri dalam hal memanggil guru yang melakukan tindak pidana memperhatikan hal-hal sebagai berikut:

a) Dalam hal tindak pidana yang berkaitan dengan profesi

(1) Surat panggilan diberikan melalui kepala sekolah langsung.

(2) Apabila kepala sekolah tidak ada disekolah, surat panggilan diberikan langsung kepada yang bersangkutan disekolah.

(3) Apabila kepala sekolah dan yang bersangkutan tidak ada di sekolah, surat panggilan dialamatkan kepada tempat tinggal yang bersangkutan.

(4) Apabila yang melakukan tindak pidana adalah kepala sekolah maka surat panggilan diberikan melalui kepala dinas. 
b) Dalam hal tindak pidana diluar profesi

(1) Surat panggilan diberikan dan/atau dialamatkan kepada yang bersangkutan.

(2) Apabila situasi tidak memungkinkan pemeriksaan dapat dilakukan menurut penilaian penyidik.

3) Pemeriksaan

Polri dalam hal melakukan pemeriksaan terhadap guru sebagai saksi atau terlapor memperhatikan hal-hal sebagai berikut:

a) Tindak pidana yang berkaitan dengan profesi

(1) Pemeriksan terhadap guru baik sebagai saksi maupun terlapor diupayakan di kantor PGRI setempat atau di tempat yang disepakati bersama antara DKGI/guru dengan penyidik, dengan tidak menyalahi peraturan perundang-undangan.

(2) Apabila situasi tidak memungkinkan maka pemeriksaan dapat dilakukan di kantor kepolisian.

b) Tindak pidana di luar Profesi

(1) Pemeriksaan dilakukan di kantor Kepolisian.

(2) Apabila situasi tidak memungkinkan pemeriksaan dapat dilakukan menurut penilaian penyidik.

4) Penggeledahan

Polri di dalam melakukan penggeledahan terhadap guru yang sedang melaksanakan kegiatan proses pembelajaran dilaksanakan dengan memperhatikan :

a) Tindak pidana yang berkaitan dengan profesi

(1) Penggeledahan terhadap guru, tidak dilakukan pada saat proses kegiatan pembelajaran.

(2) Penggeledahan terhadap guru wanita dilakukan oleh polisi wanita, didampingi guru wanita, atau warga masyarakat yang wanita.

(3) Penggeledahan terhadap tempat dan barang dilingkungan sekolah dilakukan di luar jam sekolah atau dikoordinasikan dengan kepala sekolah sesuai tingkat kebutuhan. 
b) Tindak pidana di luar profesi

(1) Dalam hal tindak pidana narkoba, terorisme, dan korupsi Polri dapat melakukan pengeledahan dengan mengabaikan perlindungan terhadap profesi guru.

(2) Diluar tindak pidana narkoba, terorisme dan korupsi Polri tetap memperhatikan perlindungan hukum, perlindungan profesi, dan keamanan kerja guru.

5) Penyitaan

Polri di dalam melakukan penyitaan terhadap barang bukti baik yang berkaitan degan profesi guru maupun tidak memperhatikan:

a) Untuk kepentingan penyidikan, penyidik berwenang menyita barang bukti.

b) Dalam hal barang bukti yang berkaitan dengan alat pembelajaran tetap dilakukan penyitaan namun demikian dapat dipinjamkan pakaikan oleh pihak sekolah sesuai prosedur hukum yang berlaku.

6) Penangkapan

Penangkapan terhadap guru yang melakukan tindak pidana memperhatikan:

a) Tindak pidana yang berkaitan dengan profesi

(1) Tidak dilakukan pada saat proses kegiatan pembelajaran.

(2) Dilakukan dengan taktik dan teknik kepolisian yang tetap memperhatikan perlindungan hukum, perlindungan profesi, dan keamanan guru.

b) Tindak pidana diluar profesi

(1) Dalam hal tindak pidana narkoba, teroris, dan korupsi Polridapatmelakukanpenangkapan dengan mengabaikan perlindungan terhadap profesi guru.

(2) Di luar tindak pidana narkoba, terorisme, dan korupsi Polri tetap memperhatikan perlindungan hukum, perlindungan 
profesi, dan keamanan kerja guru pada saat ditempat proses kegiatan pembelajaran.

(3) Di luar tempat proses pembelajaran, dapat langsung dilakukan proses penangkapan sesuai tindak pidana yang dilakukan.

7) Penahanan

Penahanan terhadap guru yang melakukan tindak pidana memperhatikan:

a) Tindak pidana yang berkaitan dengan profesi

(1) Penahanan dilakukan berdasarkan penilaian penyidik guna melindungi keselamatan jiwanya.

(2) Dapat dilakukan penangguhan penahanan sesuai dengan prosedur berdasarkan penilaian penyidik.

(3) Dapat dilakukan penahanan kota atau rumah sesuai dengan prosedur berdasarkan penilaian penyidik.

b) Tindak pidana di luar profesi

Polri dapat melakukan penahanan dengan mengabaikan perlindungan terhadap profesi guru sesuai undang-undang yang berlaku.

Berdasarkan uraian di atas, guru telah diberikan suatu upaya perlindungan terkhusus pada saat upaya paksa dilakukan, sehingga walaupun telah ada bukti awal yang menguatkan tuduhan sebagai pelaku kejahatan, guru yang bersangkutan telah tetap berkedudukan sebagai manusia dan guru dalam profesinya dengan hak asasi yang tidak boleh dilanggar. Terlebih apabila atasperbuatannya itu belum ada putusan hakim yang menyatakan pelaku bersalah (asas praduga tidak bersalah). ${ }^{8}$

MoU ini adalah salah bentuk nyata dari komitmen para pihak khususnya POLRI dan PGRI untuk melindungi kehormatan dari profesi guru serta langkah konkret dari pelaksanaan amanat undang-undang bahwa setiap elemen negara wajib memberikan perlindungan bagi guru dalam bentuk rasa aman.

${ }^{8}$ Dikdik M.Arief Mansur dan Elisatris Gultom, Urgensi Perlindungan Korban Kejahatan, (Jakarta: PT Raja Grafindo Persada, 2007), hlm. 20 
Peraturan-peraturan diatas sangatlah jelas menerangkan bahwa guru dalam melaksanakan tugas profesinya dibenarkan oleh hukum mengambil suatu tindakan atau pemberian sanksi kepada peserta didik yang telah melanggar norma atau aturan yang berlaku yang bertujuan untuk mendidik. Namun hal ini seakan rancu ketika guru dibenarkan oleh hukum untuk memberikan hukuman atau sanksi seperti mana di cantumkan pada pasal 39 ayat (2) Guru dalam memberikan sanksi harus sesuai dengan peraturan perundang-undangan, yang mana justru dalam peraturan perundangan-undangan yang lain itu dianggap bertentangan.

Seperti dalam Undang-Undang Nomor 35 Tahun 2014 tentang Perubahan Atas Undang-Undang Nomor 23 tahun 2002 tentang Perlindungan Anak dalam Pasal 9 ayat (1a) yang berbunyi:

"Setiap Anak berhak mendapatkan perlindungan di satuan pendidikan dari kejahatan seksual dan Kekerasan yang dilakukan oleh pendidik, tenaga kependidikan, sesama peserta didik, dan/atau pihak lain."

Pasal 76C menyebutkan:

"Setiap Orang dilarang menempatkan, membiarkan, melakukan, menyuruh melakukan, atau turut serta melakukan Kekerasan terhadap Anak".

Serta Pasal 80:

"Setiap Orang yang melanggar ketentuan sebagaimana dimaksud dalam Pasal 76C, dipidana dengan pidana penjara paling lama 3 (tiga) tahun 6 (enam) bulan dan/atau denda paling banyak Rp72.000.000,00 (tujuh puluh dua juta rupiah)".

Hal inilah yang menjadi dasar bagi peserta didik atau orang tua peserta didik menganggap bahwa tindakan yang dilakukan oleh guru dalam hal mendidik justru dianggap sebagai suatu pelanggaran hak anak atau pelanggaran hukum seperti dalam beberapa kasus yang menimpa profesi guru yang ramai di wartakan di berbagai media.

Berdasarkan hasil wawancara penulis dengan Bapak Akhmad Munawar S.H., M.H. Dosen Hukum Pidana di Fakultas Hukum Universitas Islam Kalimantan Muhammad Arsyad Al-Banjari Banjarmasin, beliau berpendapat terhadap kasus diatas terlihat disharmonis atau ketidak sinkronan antara peraturan peundang- 
undangan yang satu dengan yang lainnya, menyikapi permasalahan diatas seharusnya kita menggunakan asas Lex Specialis Derogat Legi Generalis dimana suatu aturan yang bersifat khusus mengesampingkan aturan yang bersifat umum.

Pada kasus diatas Undang-Undang Nomor 35 tahun 2014 tentang Perubahan Atas Undang-Undang Nomor 23 tahun 2002 tentang Perlindungan Anak, merupakan undang-undang yang sifatnya umum yang digunakan bagi tindak pidana yang korbannya anak dan pelakunya masyarakat umum, namun pada kasus pelakunya adalah guru maka seharusnya digunakanlah aturan khusus yaitu Undang-UndangNomor 14tahun 2005 tentang Guru dan Dosen, dan peraturan perundang-undangan lain yang menjadi satu kesatuan dengan undang-undang itu seperti Peraturan Pemerintah Republik Indonesia Nomor 19 Tahun 2017 tentang Perubahan Atas Peraturan Pemerintah Republik Indonesia Nomor 74 Tahun 2008 tentang Guru.

Dimana di dalam aturan yang bersifat khusus itu setiap elemen negara baik pemerintah pusat dan daerah, masyarakat, organisasi guru, dan/atau satuan pendidikan wajib memberikan perlindungan bagi guru dalam melaksanakan tugas profesinya, perlindungan yang dimaksud meliputi perlindurgan hukum, perlindungan profesi, serta perlindungan keselamatan dan kesehatan kerja. Sehingga seharusnya tindakan guru dalam memberikan sanksi yang masih dalam batas wajar yang masih sesuai dengan kaedah pendidikan tidaklah dianggap sebagai suatu tindak pidana yang pelakunya dijatuhi hukuman pidana. Lebih jauh beliau sepakat manakala peserta didik melakukan suatu kesalahan atau melanggar aturan maka guru memberikan sanksi guna mendidik bukan hanya pada pelaku tapi juga pada temantemannya bahwa pelanggaran aturan itu adalah sebuah kesalahan dan akan menimbulkan konsekuensi. Pengambilan tuindakan atau pemberian sanksi oleh guru dalam penegakkan aturan memang harus dilakukan, sebuah aturan memang bersifat memaksa manakala suatu aturan tidak dilengakapi dengan sanksi maka justru cenderung akan terjadi pelanggaran-pelanggaran terhadap aturan itu.

Terkait permasalahan diatas para pakar hukum pun berpendapat bahwa tindakan guru dalam memberikan sanksi tidak dapat di pidana, diantaranya Prof. Dr. Andi Zainal Abidin Farid, memasukkan Hak mendidik orang tua/wali, Guru sebagai 
alasan pengecualian pidana di luar KUHP. ${ }^{9}$ Mr. Van Bemmelen juga memasukkan Hak mendidik orang tua/wali, guru sebagai alasan pengecualian pidana. Menurutnya bahwa Orang tua, para guru, dan orang-orang yang bertugas mendidik, "dalam batas tertentu" berhak merampas kebebasan anak-anak yang belum dewasa, misalnya memaksa tidak boleh keluar kamar, menyuruh tinggal di kelas sesudah jam pelajaran lewat, atau menyuruh datang kembali ke sekolah pada sore hari. "ini bukanlah perampasan kebebasan secara melawan hukum". Menghukum anak-anak dengan memukul "dalam keadaan tertentu" dan "asal dijalankan secara mendidik" tidak merupakan penganiayaan. ${ }^{10}$

Leden Marpaung juga memasukkan Hak mendidik anak sebagai perluasan dasar penghapusan pidana.Secara umum dapat dipahami bahwapara orang tua atau guru diberi kewenangan tertentu dalam rangka mendidik, misalnya ${ }^{11}$ :

1. Melarang anak keluar rumah atau kamar.

2. Tinggal di kelas usai pelajaran.

3. Mendera atau memukul anak "secara terbatas"

Hal ini menurut Leden Marpaung, tidak termasuk pengertian "merampas kemerdekaan" si anak atau "Penganiayaan". Namun perlu disadari bahwa semua hal tersebut "dimaksudkan sebagai sarana untuk mendidik". ${ }^{12}$ Lebih lanjut dikatakan oleh Leden Marpaung, bahwa jika hal tersebut dilakukan dengan "melalaikan kepentingan si anak", bagaimanapun si Orang tua atau guru "dapat diminta pertanggungjawabannya". Misalnya: (1) Si anak dikurung dalam kamar berjam-jam tanpa diberi minum atau makan sehingga mengalami gangguan kesehatan. (2) memukul anak dengan kayu sehingga anak tersebut mengalami luka-luka. (contoh 1 dan 2 ) dapat dikategorikan "melampaui batas". ${ }^{13}$

Hal senada juga disampaikan oleh Bapak Lukman Hakim PS. Kanit IDIK IV Unit Perlindungan Perempuan dan Anak (PPA) Polres Banjar. Dalam wawancara dengan penulis beliau berpendapat, profesi guru adalah profesi yang terhormat

${ }^{9}$ Andi Zainal Abidin Farid, Hukum Pidana I, cet. III, (Jakarta: Sinar Grafika, 2010), hlm. 203.

${ }^{10}$ J. M. Van Bemmelen, Hukum Pidana I Hukum Pidana Material Bagian Utama (Ons Srafrecht 1 Het Materiele Srafrecht Algemeen Deel-), diterjemahkan oleh Hasnan, cet. II, (Bandung: Binacipta, 1987), hlm. 201.

71.

${ }^{11}$ Leden Marpaung, Asas-Teori-Praktik Hukum Pidana. (Jakarta: Penerbit Sinar Grafika, 2005), hlm.

\footnotetext{
${ }^{12}$ Ibid.

${ }^{13}$ Ibid.
} 
untuk itu perlu diberikan perlindungan untuk menjaga kehormatan itu, beliau mengapresiasi adanya Undang-Undang Nomor 14 tahun 2005 tentang Guru dan Dosen, dan Peraturan Pemerintah Republik Indonesia Nomor 19 Tahun 2017 tentang Perubahan Atas Peraturan Pemerintah Republik Indonesia Nomor 74 Tahun 2008 tentang Guru merupakan dasar hukum bagi kepolisian untuk memberikan perlindungan bagi guru.

Beliau menuturkan terlepas dari jabatan beliau sebagai penegak hukum beliau merasa dilema di satu sisi ada perintah undang-undang untuk melindungi profesi guru dan di satu sisi ada perintah undang-undang untuk menindak pelaku kekerasan terhadap anak, beliau bersyukur belum ada kasus seperti itu di wilayah hukum Polres Banjar. Walaupun di wilayah hukum Polres Banjar belum pernah ada kasus seperti itu namun manakala terjadi kasus seperti beliau menegaskan akan mengikuti MoU antara POLRI dan PGRI mengenai pedoman kerja antara POLRI dengan PGRI yaitu tentang mekanisme penanganan perkara dan pengamanan terhadap profesi guru.

\section{Dampak Dari Kasus-Kasus Pidana Yang Menjerat Profesi Guru Dalam Melaksanakan Tugas Profesinya}

Berdasarkan hasil wawancara penulis dengan ketua PGRI Kabupaten Banjar Bapak Drs. Muhammad Arsyad, M. Pd. Penulis menemukan berbagai dampak yang di alami para guru diantara:

1. Rasa Takut dan Kekhawatiran

Guru dalam menjalankan tugas profesinya dibayangi rasa ketakutan dan kekhawatiran akan dipolisikan manakala memberikan hukuman kedisiplinan kepada peserta didik yang melanggar aturan atau kedidiplinan ketika proses belajar mengajar.

2. Sikap Acuh

Tak sedikit guru menjadi acuh kepada peserta didiknya manakala mereka berbuat salah, guru seakan tak menghiraukan kesalahan yang telah dilakukan peserta didik.

3. Kriminalisasi dan Deskriminasi

Dalam beberapa kasus bahkan guru dikriminalisasi dan deskriminasi oleh peserta didik atau orang tua peserta didik seperti dibentak, dimarahi, 
dipukul hingga dipolisikan oleh peserta didik atau orang tua peserta didik seperti beberapa kasus yang ramai diberitakan diberbagai media diantaranya kasus penganiayaan yang dialami Aop saopudin dan akhirakhir ini ahmad budi cahyono di Sampang, Madura.

Dari dampak-dampak diatas yang dialami oleh guru menjadi salah satu faktor berkurangnya keprofesionalan dari guru, hal ini tentu saja membuat kurang optimalnya kinerja para dalam membentuk watak atau karakter para peserta didik yang merupakan para penerus bangsa sehingga tidak tercapai dari tujuan pendidikan nasional yaitu "mengembangkan kemampuan dan membentuk watak serta peradaban bangsa yang bermartabat dalam rangka mencerdaskan kehidupan bangsa, bertujuan untuk berkembangnya potensi peserta didik agar menjadi manusia yang berimandan bertakwa kepada Tuhan Yang Maha Esa, berakhlak mulia, sehat, berilmu, cakap, kreatif, mandiri, dan menjadi warga negara yang demokratis serta bertanggungjawab.

Menurut Bapak Muhammad Arsyad permalasahan seperti ini tentu tidak akan terjadi manakala setiap komponen negara melaksanakan apa yang diamanatkan undang-undang sendiri, seperti orang tua memberikan ruang atau kepercayaan kepada pendidik untuk mendidik anaknya, orang tua dan pendidik selalu berkomunikasi perihal tumbuh kembang dan permasalahan peserta didik.

Lebih lanjut menurut hemat penulis setiap komponen bangsa harus melaksanakan setiap kewajibannya masing-masing dalam hal melindungi profesi guru guna mencapai tujuan daripada pendidikan nasional seperti yang telah diatur dalam peraturan perundang-undangan, dalam Undang-Undang Nomor 20 tahun 2003 pada Pasal 6 ayat (2) diatur bahwa "Setiap warga negara bertanggung jawab terhadap keberlangsungan penyelenggaraan Pendidikan", Pasal 11 menyebutkan: "(1) Pemerintah dan Pemerintah Daerah wajib memberikan layanan dan kemudahan, serta menjamin terselenggaranya pendidikan yang bermutu bagi setiap warga negara tanpa diskriminasi. (2) Pemerintah dan Pemerintah Daerah wajib menjamin tersedianya dana guna terselenggaranyapendidikan bagi setiap warga negara yang berusia tujuh sampai dengan lima belas tahun". Dan Pasal 12 ayat 2 huruf a, "menjaga norma-norma pendidikan untuk menjamin keberlangsungan proses dan keberhasilan pendidikan". 
Untuk itu Bapak Muhammad Arsyad berharap agar pemerintah maupun penegak hukum bisa memberikan sosialisasi maupun pemahaman dan pengertian kepada seluruh orang tua atau masyarakat terkait perlindungan guru dan peran serta mereka terhadap pendidikan nasional yang merupakan tanggung jawab dari setiap komponen bangsa.

\section{PENUTUP}

\section{Kesimpulan}

Pengaturan hukum terhadap perlindungan hukum bagi guru dalam memberikan sanksi fisik dalam batas wajar terhadap peserta didik, sejatinya telah banyak diatur didalam peraturan perundang-undangan peraturan hukum lain di Indonesia seperti didalam:Undang-Undang Republik Indonesia Nomor 20 Tahun 2003 Tentang Sistem Pendidikan Nasional, Undang-Undang Republik Indonesia Nomor 14 Tahun 2005 Tentang Guru dan Dosen, MoU POLRI dengan PGRI No. B/53/XII/2012 dan No. 1003/UM/PB/XX/2012.Lebih lanjut pengambilan tindakan atau pemberian sanksi juga secara tegas diatur didalam: Peraturan Pemerintah Republik Indonesia Nomor 74 Tahun 2008 Tentang Guru, Yurisprudensi atau Putusan Mahkamah Agung Republik Indonesia No. 1554 K/PID/2013.Walaupun telah banyaknya pengaturan hukum terkait perlindungan hukum yang disematkan pada guru, nyatanya dalam prakteknya ini masih dirasa belum sepenuhnya melindungi guru dalam melaksanakan tugas profesinya mengingat banyaknya kasus-kasus hukum yang mendera guru.

Adapun dampak-dampak dari kasus-kasus pidana yang menjerat profesi guru dalam melaksanakan tugas profesinya terhadap para guru dalam menjalankan tugas profesinya antara lain: rasa takut dan kekhawatiran akan dipolisikan manakala memberi tindakan kedisiplinan kepada peserta didik, sikap acuh terhadap perbuatan salah atau pelanggaran norma yang dilakukan peserta didik, serta kriminalisasi dan deskriminasi yang dilakukan oleh peserta didik maupun orang tua peserta didik. Hal ini tentu saja berakibat pada menurunnya keprofesionalan dari guru sehingga kurang optimalnya peran guru dalam mendidik peserta didik dalam membentuk watak atau karakter para peserta didik yang merupakan para penerus bangsa sehingga tidak tercapai dari tujuan pendidikan nasional yaitu "mengembangkan kemampuan 
dan membentuk watak serta peradaban bangsa yang bermartabat dalam rangka mencerdaskan kehidupan bangsa, bertujuan untuk berkembangnya potensi peserta didik agar menjadi manusia yang beriman dan bertakwa kepada Tuhan Yang Maha Esa, berakhlak mulia, sehat, berilmu, cakap, kreatif, mandiri, dan menjadi warga negara yang demokratis serta bertanggungjawab. Hal ini terjadi karena kurangnya pemahaman peserta didik, orang tua peserta didik, masyarakat serta seluruh elemen bangsa akan perannya masing-masing dalam tanggung jawab pendidikan seakan semuanya hanya diserahkan kepada guru.

\section{Saran}

Hendaknya dalam prakteknya perlindungan hukum bagi guru ini lebih optimal ditegakkan mengingat telah banyaknya aturan hukum yang mengaturnya.Seperti amanat undang-undang bahwa dalam perlindungan bagi guru merupakan tanggung jawab bersama seluiruh komponen bangsa hendaknya lebih memperhatikan lagi terkait permalasahan yang menimpa guru terlebih perlindungan hukum. Diharapkan pemerintah meninjau ulang Undang-Undang Nomor 35 tahun 2014 tentang Perubahan Atas Undang-Undang Nomor 23 tahun 2002 tentang Perlindungan Anak. Manakala berkaitan dengan guru setidaknya diberlakukan pembatasan yang jelas sehingga tidak terjadi benturan norma atau ketidak sinkronan peraturan perundang-undangan, seperti pendapat para ahli hukum yang mengatakan Hak mendidik anak bagi guru merupakan alasan pengecualian pidana bahkan dasar penghapusan pidana, serta dengan dasar yurisprudensi Mahkamah Agung No. 1554 K/PID/2013 bahwa guru tidak dapat dipidina manakala melaksanakan tugas profesinya.

Hendaknya pemerintah dapat memberikan edukasi, pemahaman atau pengertian kepada masyarakat khususnya orang tua terkait perlindungan guru yang merupakan tanggung jawab bersama serta terkait tugas atau beban yang diemban oleh guru guna mendidik peserta didik menjadi pribadi yang beriman dan bertakwa kepada Tuhan Yang Maha Esa, berakhlak mulia, sehat, berilmu, cakap, kreatif, mandiri, dan menjadi warga negara yang demokratis serta bertanggungjawab. Hendaknya orang tua tidak hanya menyerahkan tanggung jawab mendidik pada Pendidik sepenuhnya dan manakala terjadi suatu kesalahpahaman langsung 
menyalahkan Pendidik sebagai yang bertanggung jawab sepenuhnya atas itu, hendaknya orang tua dan Pendidik membangun komunikasi terkait tumbuh kembang serta permasalahan yang dialami peserta didik, sehingga dapat menghasilkan solusi yang terbaik bagi peserta didik maupun semua pihak. Selain itu, seyogyanya orang tua dapat memberikan ruang atau kepercayaan kepada guru dalam mendidik anak mereka, sehingga manakala terjadi suatu kesalahpahaman atau kekeliruan dapat diselesaikan secara damai dan kekeluargaan.

\section{DAFTAR PUSTAKA}

\section{Buku}

Atmasasmita, Romli. 1995. Kapita Selekta Hukum Pidana dan Kriminologi. Bandung: Mandar Maju.

1996. Sistem Peradilan Pidana. Bandung: Binacipta.

Bahri, Syaiful. 2009. Guru dan Anak Didik. Jakarta: Rineka Cipta.

Bemmelen, J. M. Van. 1987. Hukum Pidana I Hukum Pidana Material Bagian Utama (Ons Srafrecht 1-Het Materiele Srafrecht Algemeen Deel-), diterjemahkanolehHasnan, cet. II, Bandung: Binacipta.

Chazawi, Adami. 2002. Pelajaran Hukum Pidana Bagian I. Jakarta: PT. Raja Grafindo Persada.

Hadjon, Pjillipus M. 1987. PerlindunganHukumbagi Rakyat Indonesia, Surabaya: BinaIlmu.

Hasibuan dan Moedjiono. 1985. Proses Belajar Mengajar. Bandung: PT. Remaja Rosdakarya.

Kansil, C.S.T. 1989. Pengantar Ilmu Hukum dan Tata Hukum Indonesia. Jakarta: Balai Pustaka.

Lamintang, P.A.F. 1997. Dasar-Dasar Hukum Pidana Indonesia. Bandung: Penerbit PT. Citra Aditya Bakti.

Marpaung, Leden. 2005 Asas-Teori-Praktik Hukum Pidana. Jakarta: Penerbit Sinar Grafika.

Moeljatno. 1993. Perbuatan Hukum dan Pertanggungjawaban Dalam Hukum Pidana. Jakarta: Bina Aksara. 
Muladi. 1995. Kapita Selekta Sistem Peradilan Pidana. Semarang: Badan Penerbit Universitas Diponegoro.

M. Arief Mansur, Dikdik. Dan Elisatris Gultom. 2007. Urgensi Perlindungan Korban Kejahatan. Jakarta: PT. Raja Grafindo Persada.

Narbuko, Choliddan Abu Achmadi. 2001. Metodologi Penelitian. Jakarta: Bumi Aksara.

Purwanto, M. Ngalim. 1995. Ilmu Pendidikan. Bandung: Remaja Rosdakarya.

Sarwono. 1992. Pengantar Umum Pendidikan. Jakarta: Rineka Cipta.

Sholehuddin. 2002. Sistem Sanksi dalam Hukum Pidana, Ide Dasar Double Track System dan Implementasinya. Jakarta: Raja Grafindo Persada.

Soekanto, Soerjono. 1981. Pengantar Penelitian Hukum. Jakarta: UI Press.

Soemitro, Ronny Hanitijo. 1994. Metode Penelitian Hukum dan Yurimetri. Jakarta: Ghalia.

Sudarto. 1986. Kapita Selekta Hukum Pidana. Bandung: Alumni.

Sugiyono. 2010. Metode Penelitian Kunatitatif Kualitatif dan R\&D. Bandung: Alfabeta.

Supranto, J. 2003. Metode Penelitian Hukum dan Statistik. Jakarta: PT Rineka Cipta.

Sumali. 2003. Reduksi Kekuasaan Eksekutif di Bidang Peraturan Pengganti Undangundang (Perpu). Malang: UMM Press .

Uno, H. Hamzah B. 2009. Profesi Kependidikan Problema, Solusi, dan Reformasi Pendidikan di Indonesia. Jakarta: Bumi Aksara.

Widiastono, Tony D. 2004. Pendidikan Manusia Indonesia. Jakarta: Penerbit Buku Kompas.

Yati Nurhayati, Ifrani, \& M. Yasir Said, (2021), Metodologi Normatif dan Empiris Dalam Perspektif Ilmu Hukum, Jurnal Penegakan Hukum Indonesia, Vol. 2, No.1, Tahun 2021.

Zainal Abidin Farid, Andi. 2010. Hukum Pidana I, cet. III, Jakarta: Sinar Grafika.

\section{Peraturan Perundang-Undangan}

Undang-Undang Dasar Negara Republik Indonesia Tahun 1945 
Undang-Undang Nomor 1 Tahun 1946 tentang Peraturan Hukum Pidana atau selanjutnya disebut Kitab Undang-Undang Hukum Pidana (KUHP).

Undang-Undang Republik Indonesia Nomor 8 Tahun 1981 tentangKitabUndangUndangHukumAcaraPidana.

Undang-Undang Republik Indonesia Nomor 20 Tahun 2003 Tentang Sistem Pendidikan Nasional.

Undang-Undang Republik Indonesia Nomor 14 Tahun 2005 Tentang Guru dan Dosen.

Undang-Undang Republik Indonesia Nomor 23 Tahun 2002 Tentang Perlindungan Anak Jo. Undang-Undang Republik Indonesia Nomor 35 Tahun 2014 Tentang Perubahan Atas Undang-Undang Republik Indonesia Nomor 23 Tahun 2002 Tentang Perlindungan Anak.

Peraturan Pemerintah Republik Indonesia Nomor 74 Tahun 2008 Tentang Guru Jo. Peraturan Pemerintah Republik Indonesia Nomor 19 Tahun 2017 Tentang Perubahan Atas Peraturan Pemerintah Republik Indonesia Nomor 74 Tahun 2008 Tentang Guru.

Yurisprudensi atau Putusan Mahkamah Agung Republik Indonesia No. 1554 $\mathrm{K} / \mathrm{PID} / 2013$ 